\title{
PESANTREN TRANSFORMATIF: RESPON PESANTREN TERHADAP PERUBAHAN SOSIAL
}

\author{
HM Atho Mudzhar
}

\begin{abstract}
The life of the community changes constantly with time. Today there bave been changes in various aspects of life. Therefore, Indonesia, Moslems, and Islamic boarding school (pesantren) community all are parts of educational world itself. In this context, it is necessary for pesantren to thing more clearly, more society changes constantly with the twice circle. As a past of national education system, pesantren needs to be adaptive and accommodative to the process of social change occurred. Pesantren needs to play any constructive role in developing the surrounded community at any aspects of life, both religious aspect and socio cultural and economic aspect. In this context, the article aims at to elaborate on how pesantren should accommodate the recent development without disregarding the predetermined vision and mission.
\end{abstract}

Keywords: social cultural changes, pesantren

Prof Dr HM Atho Mudzhar adalah

Kepala Badan Litbang dan Diklat

Departemen Agama RI

\section{Pendahuluan}

Pendidikan merupakan kunci keberhasilan dalam peningkatan kualitas manusia, bahkan jika pendidikan diartikan dalam pengertian luas, maka pendidikan merupakan faktor penentu kualitas hidup manusia. Baik-buruknya kualitas hidup dan prilaku individu, masyarakat, atau bangsa, sangat tergantung pada bagaimana kualitas penyelenggaraan pendidikan itu sendiri - termasuk arah, landasan filosofis, kurikulum, metoda, dan lingkungan pendidikan, dsb. Atas pemahaman terhadap konsep pendidikan inilah, 
maka kajian ikhwal pendidikan pesantren secara tematis tetap menjadi penting, relevan, dan kontekstual, terutama dalam konteks perubahan sosial. ${ }^{1}$

Kehidupan masyarakat senantiasa terus berubah sesuai perjalanan waktu. Tentu saja, tak terbayangkan sebelumnya, bahwa kurang lebih sepuluh tahun lalu hingga hari ini, kita bisa menyaksikan betapa telah terjadi perubahan yang demikian menyolok dalam berbagai aspeknya di tengah kehidupan kita - jika dibandingkan dengan waktu sebelumnyakarena berbagai faktor. Berkat kemajuan teknologi komunikasi dan puncak kebebasan manusia, misalnya, kini kita dapat menyaksikan fenomena cyber society (bangunan masyarakat maya dengan teknologi komunikasi canggih), komunikasi jarak jauh tanpa jarak (teleconference, telediscussion, dan sejenisnya), lining without boundaries (hidup tanpa sekat teritori), orientasi hidup nihilisme yang meniadakan kebenaran moral, serta fenomena berbagai perubahan gaya hidup berteknologi canggih, berkebebasan mondial, dan berteleliteratur, dan fenomena postmodern lainnya. Fenomena perubahan itu semua--yang terjadi pada hampir semua aspek kehidupan : sosial, politik, ekonomi, budaya, dan keagamaan—sudah barang tentu, tidak bisa diabaikan begitu saja. $\mathrm{Hal}$ ini, karena, bagaimana pun kita bangsa Indonesia, umat Islam, komunitas pesantren adalah bagian dari sistem dunia kehidupan itu sendiri. Dalam konteks inilah, pesantren — sebagai lembaga pendidikan Islam yang memiliki visi dan misi keislamanan-sudah barang tentu perlu

'Perubahan sosial (social change) yang dimaksud di sini adalah "setiap perubahan yang tak terulang dari sistem sosial sebagai satu kesatuan" (Hawley, 1978), "transformasi dalam organisasi masyarakat, pola berpikir, dan prilaku pada waktu tertentu" (Macionis, 1987); "modifikasi atau transformasi dalam pengorganisasian masyarakat" (Persell, 1987); "perubahan pola prilaku, hubungan sosial, lembaga dan struktur sosial pada waktu tertentu" (Farley, 1990). Lihat :Piotr Sztompka. 2004. Sosiologi Perubahan Sosial. terj. Alimandan. Jakarta: Prenada Media, h.3.

Sementara dalam perspektif ekonomi, pendidikan dipandang sebagai salah satu alat paling efektif dalam peningkatan kesejahteraan ekonomi masyarakat. Blaugh dalam An Introduction to Economics in Education (1973 : 3) merumuskan pendidikan sebagai "human capital investment", di mana melalui investasi modal manusia ini, maka manusia diproses sedemikian rupa sehingga memiliki pengetahuan, sikap dan keterampilan yang fungsional dan kontributif bahkan menentukan tingkat kesejahteraan hidupnya. Secara makro, Theodore W. Schultz dalam "Investment in Human Capital" menyimpulkan bahwa tingkat pertumbuhan ekonomi ditentukan oleh investasi modal manusia. Lihat : Power And Ideology in Education, J. Karabel 
memikirkan lagi secara lebih jernih, lebih komprehensif, dan lebih sistemik tentang bagaimana memosisikan dan memungsikan pesantren dalam konstelasi perubahan sosial-budaya yang tengah terjadi ini. Dengan demikian, pembincangan pesantren dalam konteks perubahan sosial menjadi tetap relevan untuk didiskusikan. Paling tidak, diharapkan lewat diskusi komprehensif dan terbuka, dapat memberikan masukan "seperti apa pesantren seharusnya mengakomodir perkembangan yang terjadi tanpa harus melenceng dari visi \& misi yang digariskan".

Pesantren sebagai bagian dari sistem pendidikan nasional, diberi kewenangan untuk melakukan pengembangan dan penataannya agar mampu menjalankan fungsi secara memadai di tengah perkembangan kebutuhan masyarakat penggunanya. Undang-undang $R I$ nomor 20 Tahun 2003 tentang Sistem Pendidikan Nasional, pasal 30 yang dijabarkan dalam Peraturan Pemerintah Nomor 55 Tabun 2007 tentang pendidikan keagamaan, misalnya, menunjukkan adanya perhatian Pemerintah akan kedudukan, peran, dan fungsi pesantren dalam pengembangan kualitas hidup ummat. Dalam konteks kebijakan inilah pentingnya sebuah kajian secara terus menerus tentang bagaimana seharusnya pesantren memosisikan diri dan memaksimalkan perannya dalam pembinaan umat pada situasi aktual yang terjadi sekarang dan mendatang.

\section{Pesantren dari Masa ke Masa:Selayang Pandang}

Pesantren sebagai bagian dari sistem pendidikan nasional, memiliki sejarah panjang sesuai dengan dinamika perkembangan tuntutan zamannya.

dan A.H. Halsey (Ed.), 1977 : 313-315. Dalam perspektif sosial-politik, pendidikan yang dirumuskan sebagai proses sosialisasi nilai-nilai kehidupan berpolitik, bersosial, atau proses pembentukan budaya berpolitik berkontribusi besar dalam pencapaian tujuan pembangunan nasional. Lihat: Tom Brennan, dalam Political Education and Democracy, Cambridge University Press, 1981, hal. 19. Melalui proses pendidikan, masyarakat distrukturir dan dibimbing untuk memahami, menghayati dan mengamalkan hak dan kewajibannya sebagai warga negara secara memadai. Selanjutnya dalam perspektif sosial-budaya yang memahami pendidikan sebagai upaya penànaman nilai dan norma budaya (proses pembudayaan atau proses sivilisasi), pendidikan merupakan unsur sangat strategis dalam upaya pelestarian, pengembangan dan pembaruan nilai dan norma budaya masyarakat. Pendidikan mengupayakan terbentuknya pola perilaku yang adaptif dan sesuai dengan kebutuhan masyarakat). Kemudian, perspektif filosofis, pendidikan merupakan upaya pemanusiaan manusia (humanization of human being). 
Pada awal perkembangannya di Indonesia, misalnya, kira-kira 7-8 abad lalu, pesantren memokuskan pada upaya penyebaran Islam di Nusantara. Pesantren ketika itu, selama beberapa abad, melakukan kegiatan Islamisasi dan purifikasi ajaran.

Perkembangan berikutnya pada masa penjajahan, pesantren memosisikan dirinya sebagai sentra perlawanan terhadap Belanda atau berbagai bentuk kolonialisme lainnya, selain tetap sebagai tempat belajar dan pusat penyebaran Islam. Apa yang diperlukan bangsa pada saat itu adalah bagaimana menumbuhkan nasionalisme dan patriotisme, dan menggelorakan semangat jihad melawan kolonialisme dan imperialisme untuk mengusir dan memerdekaan bangsa dari kungkungan bangsa lain. Tampak, komunitas pesantren bersama para nasionalis-sekular berhasil meraih kemerdekaan Indonesia.

Pada awal kemerdekaan, antara tahun 1945-1968, pendidikan pesantren kembali mewujudkan misi penyebaran agama disamping tetap melakukan penguatan semangat dan patriotisme dan kebangsaan agar tetap mampu melanjutkan perjuangan bangsa mencapai citacitanya. Pada saat ini, pendidikan pesantren atau pendidikan lainnya memerlukan penumbuhan rasa kebangsaan, persatuan, dan semangat membangun bangsa yang baru lepas dari kungkungan kolonialisme, imperialisme, dan feodalisme. Politik pendidikan ditekankan pada pengembangan dan penguatan "national and character building".

Pada awal Orde Baru, terutama sejak dimulainya Pembangunan Jangka Panjang (PJP I), saat kebijakan pendidikan diorientasikan pada pewujudan masyarakat demokratis, rasional dan pemilikan keterampilan teknis, maka sebagain besar pesantren berupaya pula membantu dalam berbagai kiprah pembangunan. Tercatat pada masa Orba itu, pesantren mampu membantu menyukseskan program keluarga berencana dan program pembangunan lainnya, terutama di daerah perdesaan.

Pada PJP II yang dimulai sejak 1994 dan direncanakan berakhir pada tahun 2019, kebijakan pembangunan sektor pendidikan mengalami perubahan. Pada awal PJP II (Pelita I) kebijakan pendidikan diarahkan pada upaya peningkatan mutu sumber daya manusia (SDM) yang disesuaikan dengan kebutuhan nyata (real needs) bangsa yang tengah menjalani proses industrialisasi. Pada saat inilah, pesantren mengalami perubahan orientasi relatif menyolok. Ragam pesantren pun menjadi sangat bervariasi dilihat dari orientasi dan serta strategi pembelajarannya. Dalam konteks ini, paling tumbuh tiga kategori pesantren : salafiyah, 
khalafiyah, dan pesantren kombinasi. ${ }^{2}$ Tercatat hingga tahun 2005, terdapat 14.798 pesantren yang tersebar di seluruh pelosok Indonesia yang mengasuh hampir 3,5 juta santri, yang sebagian besar tersebar di pula Jawa.

Tabel 2: Distribusi Pesantren Di Indonesia

\begin{tabular}{|c|l|c|c|c|c|}
\hline \multirow{2}{*}{ No } & \multirow{2}{*}{ Provinsi } & \multicolumn{2}{|c|}{ Pesantren } & \multicolumn{2}{c|}{ Santri } \\
\cline { 3 - 6 } & & Jumlah & $\%$ & Jumlah & $\%$ \\
\hline 1 & Jawa Barat & 3.661 & 24,73 & 620.712 & 17,90 \\
\hline 2 & Jawa Timur & 3.582 & 24,20 & 1.169 .256 & 33,75 \\
\hline 3 & Jawa Tengah & 2.187 & 14,78 & 442.862 & 12,78 \\
\hline 4 & Banten & 1.536 & 10,38 & 204.435 & 5,90 \\
\hline 5 & Nanggroe AD & 1.007 & 6,80 & 273.824 & 7,90 \\
\hline 6 & Propinsi lain & 2.824 & 19,01 & 753.245 & 12,74 \\
\hline Jumlah 33 Propinsi & 14.798 & 100 & 3.464 .334 & 100 \\
\hline
\end{tabular}

Dari gambaran historis singkat di atas, dapat digaris-bawahi bahwa pesantren sebagai lembaga pendidikan Islam, ternyata mengalami perubahan-baik dalam orientasi, kurikulum, maupun strategi pembelajarannya. Lantas, bagaimana pesantren memosisikan dirinya di masa akan datang?

\section{Perubahan Sosial dan Tantangan Masa Depan}

Seiring dengan perjananan waktu, dewasa ini kita saksikan terjadinya perubahan sosial demikian dahsyatnya sehingga pada tingkat tertentu sulit terkendali.

Sebagai dampak proses globalisasi--yang membawa modernitas-terjadi perubahan kehidupan yang demikian dahsyat di berbagai penjuru dunia, tak terkecuali kehidupan masyarakat Indonesia. Banyak hal seperti : paradigma, cara berpikir, kebiasaan, life-style yang kita anggap biasa tiba-tiba berubah total bahkan menghilang tanpa bekas. Kondisi

${ }^{2}$ Pesantren salafiyah merupakan jenis pesantren yang berorientasi mengajarkan pengetahuan agama sepenuhnya (tafaquh fi addin), dengan metoda sorogan bandungan. Pesantren salafiyah sering dikategorikan sebagai pesantren tradisional 
seperti ini terjadi dalam arus globalisasi. Globalisasi ${ }^{3}$ tak hanya mengubah tata cara kehidupan dalam bidang ekonomi, tapi juga dalam bidang sosial, politik, budaya, agama, dan lainnya.

Dalam bidang politik, gelombang globalisasi menyebabkan hilangnya polarisasi hubungan antar negara, bangsa, atau masyarakat. Di era ini, tak ada lagi hubungan bipolar: Barat versus Timur, negara industri maju versus negara berkembang, negara demokrasi versus negara totaliter, dsb. Konstelasi politik era globalisasi mengarah pada kerangka multipolar. Dengan demikian, perdagangan atau transaksi apa pun tidak lagi bersifat hubungan dua negara tetapi dengan berbagai negara. Selain itu, peran negara, dalam bingkai globalisasi, tidak lagi dominan. Sebaliknya, peran LSM atau organisasi nonpemerintah semakin kuat, lantaran ruang publik semakin luas. Namun demikian, hubungan antar negara cenderung semakin kuat dan saling tergantung dalam berbagai bidang: politik, keamanan, ekonomi, sosial, lingkungan hidup, dan HAM.

Dalam bidang budaya, demikian pula, mengalami perubahan begitu dahsyat. Sebagai dampak kemajuan iptek, terutama teknologi komunikasi dan informasi, nyaris tidak ada perbedaan menyolok antara tata budaya satu negara/bangsa dengan negara/bangsa lainnya Globalisasi menciptakan keterkaitan (interconnectedness) antar masyarakat sejagat. Globalisasi mencipta kampung global (global village), globalisme, juga budaya global

karena menekankan pada pengajaran kitab kuning (karya-karya besar produk abad keemasan peradaban Islam pada abad 9-13 Masehi). Pesantren khalafiyah/Ashiriyahyang juga disebut pesantren modern- merupakan jenis pesantren yang menyelenggarakan pendidikan formal-klasikal yang mengajarkan pengetahuan umum (yang dianggap dasar dan penting, seperti bahasa Inggeris, Bahasa Indonesia, dan pengetahuan umum lainnya) di samping pengetahuan agama. Di antara pesantren khalafiyah, banyak pula pesantren yang menyelenggarakan pendidikan persekolahan dengan menggunakan kurikulum Depag atau Depdiknas. Sementara, pesantren kombinasi merupakan jenis pesantren - baik salafiyah maupun khalafiyah-ditambah dengan materi yang berorientasi pada pemberdayaan masyarakat sekitar. Jenis pontren ini sering diasebut pula "pesantren-Plus".

${ }^{3}$ Istilah globalisasi (globalization)-yang pertama kali digunakan pada sekitar tahun 1960-an, memiliki banyak arti. Martin Albrow dalam Globalization, Knowledge and Society (Sage, London, 1990, hal.3-13) mendefinisikan globalisasi sebagai "proses dimana umat manusia di dunia menyatu menjadi bentuk masyarakat tunggal". Ronald Robertson, dalam Globalization: Social Theory and Global Culture (Sage, London, 1992, hal.24) menggambarkan bahwsa "dunia menjadi sebuah mall perbelanjaan, dimana gagasan dan produk tersedia di semua tempat pada waktu yang sama". Singkatnya, globalisasi merupakan proses relasin sosial yang berakibat terwujudnyaa kualitas relatif tak berjarak dan tak berbatas. 
dan konsumerisme - terutama dalam hal orientasi, gaya hidup, maupun jenis food, fashion, dan fun yang diminatinya.

Menyikapi perubahan sosial yang mengglobal tersebut, sekelompok komunitas sosial demokrat betkonggres di Paris pada tahun 1999, dan mengeluarkan Deklarasi Paris, ${ }^{4}$ yang berisikan tawaran agenda/program menghadapi gelombang globalisasi yang tengah terjadi dan yang akan datang.

Pertama, program melawan kemiskinan. Globalisasi tak hanya berdampak positif tapi juga berdampak negatif yang mengakibatkan semakin miskinnya negara-negara bersumber daya manusia berkualitas rendah. Negara/masyarakat miskin ini-yang sebagian besar negara kategori developing countries dan underdeveloped countries perlu mendapatkan bantuan. Masalah kemiskinan dipandang merupakan tanggung jawab bersama masyarakat internasional.

Kedua, program memperjuangkan hak asasi manusia (HAM). Globalisasi dapat menginjak-injak hak asasi manusia atau masyarakat, terutama jikalau suatu tindakan sosial-ekonomi didasarkan pada motif keuntungan atau kekuasaan semata. HAM harus dipelihara agar dapat mengembangkan demokrasi yang merupakan syarat terbangunnya pasar bebas dan terbuka serta terjalinnya hubungan kondusif antar bangsa.

Ketiga, program menciptakan dan memelihara tatanan dunia yang aman. Pembangunan, perdagangan bebas, HAM tidak dapat diwujudkan dalam dunia yang kacau dan tidak aman. Karena itulah, memelihara keamanan dunia menjadi tanggung jawab bersama masyarakat internasional. Dalam konteks ini, Perserikatan Bangsa-Bangsa, mengagendakan perlunya membangun keamanan bersama (collective security), dengan memberi perhatian dan pengatasan terhadap: 1) ancaman sosial-ekonomi, termasuk kemiskinan, kerusakan lingkungan, dan penyakit infeksi; 2) konflik antar negara; 3) konflik internal, termasuk civil war (perseteruan antar warga, suku, agama, kampung), genocide, dsb.; 4) senjata nuklit, radiologi, kimia, dan biologi; 5) terorisme, dan 6) kejahatan transnasional. ${ }^{5}$

Keempat, program mewujudkan tatanan ekonomi dan keuangan yang baru. Lembaga-lembaga ekonomi dan keuangan lama yang terlahir

${ }^{4}$ Shimon Peres, Shaping Globalization, 2000, p.167-191

5United Nations. 2004. A More Secure World: Our Shared Responsibility, Report of the Secretary-General High-level Panel on Threats, Challenges and Change, h. 2. 
pada masa Perang Dingin serta tatanan dunia lama, seperti IMF, World Bank, WTO, perlu ditata kembali agar sesuai dengan tuntutan hidup internasional yang baru.

Kelima, program pemeliharaan lingkungan (planet bumi). Pemeliharaan dan perlindungan ekosistem merupakan tanggungjawab bersama setiap manusia, masyarakat atau bangsa di bumi, karena kerusakan lingkungan berakibat pada kesengsaraan masyarakat sejagat (contoh : global warming yang terjadi dengan segenap akibatnya).

Kenam, program kerjasama regional dalam rangka kerjasama internasional, yang menyangkut kerjasama regional, kerjasama bilateral atau kerjasama nasional dalam rangka kerjasama regional atau internasional.

Globalisasi sebagai proses tak terelakkan, dalam kecenderungannya, ternyata tidak hanya mempengaruhi atau mengubah tatanan kehidupan pada tataran makro, namun juga mengubah tata kehidupan pada tataran mikro, misalnya terhadap ikatan kehidupan sosial masyarakat. Fenomena disintegrasi sosial, hilangnya nilai-nilai tradisi, lunturnya adat-istiadat, sopan santun, dan penyimpangan sosial dalam berbagai modus operandi-nya seperti: kenakalan remaja, vandalisme, dsb. merupakan sederatan contoh yang secara langsung atau tidak langsung diakibatkan oleh proses globalisasi. Selanjutnya, sebagai reaksi terhadap realitas tersebut, munculnya fenomena contra-culture yang mewujud dalam bentuk gerakan, idiologi, faham, aliran atau life-style yang secara diametral berbalikan dengan fenomena yang berkembang. Kemunculan gerakan keagamaan radikal, suburnya fanatisme beragama, munculnya aliran keagamaan baru, model busana abaya pada dasarnya merupakan gerakan melawan budaya global yang berkembang dewasa ini. Lantas bagaimana sikap lembaga pendidikan terhadap fenomena global tersebut? Bagaimana sikap pesantren sebagai lembaga pendidikan Islam?

\section{Pesantren Transformatif Indonesia : Sebuah Alternatif}

Pesantren merupakan lembaga pendidikan keagamaan (keislaman). Sebagai lembaga pendidikan keislaman, pesantren pada dasarnya merupakan agen perubahan dalam berbagai aspeknya. Dalam spektrum luas, pesantren merupakan agen peradaban (pengadaban), agen pembelajaran, serta agen perubahan sosial-ekonomi masyarakat yang dilandaskan pada nilai-nilai ajaran Islam. Seiring dengan perjalanan waktu, dalam menjalankan tugas/fungsinya, maka ke depan pesantren niscaya perlu 
memperhatikan perubahan sosial yang terjadi. Untuk itu, pesantren ke depan perlu memperhatikan atau mengagendakan beberapa hal berikut.

Pertama, pesantren perlu memosisikan sebagai lembaga pendidikan keagamaan (keislaman) yang tetap menjadi sentra tafaqquh. fid dien yang berfungsi memelihara, mengembangkan dan memanfaatkan ilmuilmu atau ajaran Islam. Namun demikian, dalam strategi pembelajarannya, pesantren tidak perlu anti-iptek modern. Sebaliknya, pesantren dapat memanfaatkan teknologi komunikasi \& informasi untuk mencapai efrektifitas pembelajarannya.

Kedua, pesantren dapat mengembangkan ilmu-ilmu "sekular" semaksimal mungkin dalam upayanya beradaptasi dengan kemajuan iptek yang berkembang dan dibutuhkan masyarakat. Namun demikian, pesantren tetap mengembangkan ajaran Islam sesuai misi awal kehadiran pesantren itu sendiri, yakni menyebarkan ajaran Islam. Dalam konteks ini, pesantren diharapkan dapat menjalankan fungsi Islamisasi ilmu (Islamization of sciences), melalui berbagai pendekatan integratif. Dalam kerangka ini, pesantren dapat menyelenggarakan pendidikan persekolahan/ madrasi yang memokuskan pada pengembangan kompetensi penguasaan iptek yang Islami.

Ketiga, sebagai lembaga pengadaban, pesantren sudah saatnya memperhatikan tuntutan idiologi global yang berkembang. Disamping menjalankan fungsi pemeliharaan atau pelestarian nilai-nilai lokal (localities) yang baik, positif, dan bermanfaat (seperti pelestarian tradisi, adat-istiadat), pesantren juga sudah saatnya mengadaptasi dan memanfaatkan nilai-nilai global-selama positif, bermanfaat, dan tidak menghancurkan lokalitas. Penyadaraan akan pentingnya menghormati hak-hak dasar (termasuk kebebasan beragama), dan pengembangan sikap toleran (toleransi) terhadap perbedaan suku, ras, agama, bahasa, dsb. yang ada dalam masyarakat merupakan suatu concern pesantren kini dan ke depan. Karena itulah, pengembangan inklusivisme beragama merupakan tugas pesantren yang niscaya. Sebaliknya, eklusivisme beragama, fanatisisme, ekstremisme agama, sudah saatnya dikurangi pesantren sebagai pusat peradaban. Pesantren sebagai anggota masyarakat global, justeru, perlu melakukan penguatan demokrasi dan budaya keterbukaan.

Keempat, sebagai agen perubahan sosial-ekonomi, yang notabene merupakan lembaga pendidikan "dari, oleh dan untuk" masyarakat, atau lembaga pendidikan berbasis mastarakat, maka pesantren dituntut 
betpartisipasi aktif dalam pemecahan masalah perekonomian masyarakat sekitarnya. Pesantren-yang sebagian berada di daerah perdesaandiharapkan menjadi pusat perubahan ekonomi perdesaan.

Kelima, dalam aspek kurikulum (isi pendidikan), pesantren perlu mengembangkan keunggulan sesuai visi, misi, dan tuntutan perkembangan kebutuhan masyarakat, dengan memanfaatkan kemajuan iptek yang berkembang.

Demikian sekelumit paparan ikhwal perubahan sosial sebagai akibat dari terjadinya perubahan waktu dan ruang, dan bagaimana pesantren sebagai institusi pendidikan seharusnya memosisikan keberadaannya dan menjalankan fungsinya di tengah hiruk pikuk perubahan rang terjadi.

Dapat digaris-bawahi bahwa pesantren yang memerankan multifungsi bagi pengembangan komunitas (ummat) sudah saatnya memosisikan diri sebagai transformator perubahan, agar pesantren tetap relevan dengan aspirasi dan kebutuhan ummat/masyarakat yang senantiasa mengalami perubahan.

\section{SUMBER BACAAN}

Agama RI, Departemen (2004/2006): Statistik Pendidikan Agama \& Keagamaan. Jakarta, Direktorat Jenderal Kelembagaan Islam.

Albrow, Martin (1990): Globalization, Knowledge and Society. London, Sage. Blaugh (1973): An Introduction to Economics in Education.

Brennan, Tom: Political Education and Democracy. Cambridge, University Press, J. Karabel dan A.H. Halsey (1977): Powver And Ideology in Edwatio.

Peres, Shimon (200): Shaping Globalization.

Robertson, Ronald (1992): Globalization : Social Theory and Global Culture. London, Sage.

Schultz, Theodore W. "Investment in Human Capital"

Sztompka, Piotr (2004): Sosiologi Perubaban Sosial. Terj. Alimandan. Jakarta, Prenada Media.

United Nations (2004): A More Secure World: Our Shared Responsibility, Report of the Secretary-General High-level Panel on Threats, Challenges and Change. 